\title{
Adoption of Modern Hive Beekeeping Technology: The Case of Kacha-Birra Woreda, Kembata Tembaro Zone, Southern Ethiopia
}

\author{
Akililu Mulatu, ${ }^{1}$ Senapathy Marisennayya $\mathbb{D}^{\circ},{ }^{2}$ and Elias Bojago $\mathbb{i}^{3,4}$ \\ ${ }^{1}$ Agricultural Office and LIFT Program, Kembata Tambara Zone, Ethiopia \\ ${ }^{2}$ Department of Rural Development and Agricultural Extension, College of Agriculture, Wolaita Sodo University, P. O. Box 138, \\ Wolaita Sodo, Ethiopia \\ ${ }^{3}$ Department of Environmental Science, Wolaita Sodo University, P. O. Box 138, Wolaita Sodo, Ethiopia \\ ${ }^{4}$ Department of Climate Change and Sustainable Agriculture, Hawassa University, Hawassa, Ethiopia
}

Correspondence should be addressed to Elias Bojago; eliasboja77@gmail.com

Received 18 October 2021; Revised 5 November 2021; Accepted 25 November 2021; Published 20 December 2021

Academic Editor: Mudassar Iqbal

Copyright (C) 2021 Akililu Mulatu et al. This is an open access article distributed under the Creative Commons Attribution License, which permits unrestricted use, distribution, and reproduction in any medium, provided the original work is properly cited.

Beekeeping is one of the livelihood options available to Ethiopian farmers. The objectives of this study were to analyze the level of adoption of modern hive technology by farmers and to identify the variables influencing the adoption of modern beekeeping hive technology in Kacha-Birra Woreda. Primary data were collected from 89 respondents chosen using a multistage sampling process, while qualitative data were collected through focus group discussion and key informant interviews. Data were analyzed using a binary logit regression model and descriptive statistics. According to the results of the model, several factors, such as the educational level of the respondents, the size of the land, the extension, the contact, and the access to financing and market, had a substantial impact on the adoption of modern hive beekeeping technology. It is suggested that the Livestock and Fish Resource Development office develops a strategy to help the community's illiterate members benefit more from the use of contemporary hive beekeeping technologies, develops a strategy to benefit farmers who have large land sizes with modern hive beekeeping technology, establishes extension contact with farmers before technology innovation leads to better adoption of technology, and strongly advises to link a strategy with micro-enterprises. Promotional activities focused on preventing the access to the market of respondents that must ensure their active participation in adoption.

\section{Introduction}

1.1. Background of the Study. Agriculture is Ethiopia's main economic sector, accounting for roughly half of the country's GDP and employing $85 \%$ of the people. It also accounts for $90 \%$ of export revenue and $70 \%$ of the country's raw material requirements [1].

Rural livelihoods are strongly conditioned by the environments in which they are pursued. Ethiopia's agricultural production is characterized and determined by smallholder, rain-fed agriculture practices [2]. However, according to government data, the country's per capita food production has been dropping for nearly 30 years, and the country's ability to feed its growing population (3\% per year) is deteriorating from bad to worse. Between 1985 and 1998, food output fell by $45 \%$. Ethiopia has become the world's largest recipient of food aid as a result of widespread food insecurity. As a result, the demand for food aid has risen by $2.3 \%$ every year, accounting for $9 \%$ of total supplies [3]. While Ethiopia receives $12 \mathrm{~kg}$ of food aid per year, sub-Saharan Africa receives $9 \mathrm{~kg}$ [4].

Among the main reasons for Ethiopian agriculture's poor performance are shrinking farm size and subsistence farming, soil degradation, insufficient and variable rainfall, tenure insecurity, a weak agricultural research base and extension system, lack of financial services, imperfect agricultural markets, and poor infrastructure [5]. Due to low productivity and low income from agriculture, farmers resort to subsidiary enterprises to augment their incomes and ensure and improve their livelihoods [6]. One of the agro- 
based activities undertaken by various farmers in the study region and elsewhere is beekeeping. In reality, with an estimated yearly income of 360-480 (US\$45-60) million from total annual honey production [7], beekeeping plays an important role in the country's national economy, serving as a source of additional income for hundreds of thousands of farmers [7].

The ideal climatic conditions and the diversity of floral resources allow the country to sustain around 10 million honeybee colonies, of which 7 million are kept in local bee hives. The remaining exist in forests as wild colonies [7].

As a result, the country has the highest bee density in Africa. Ethiopia ranks fourth in the world in beeswax production, behind China, Mexico, and Turkey [7]. Ethiopia is also the largest honey producer, with 24,000 tons produced annually, representing $24 \%$ of African production, or over 450 million birr. Furthermore, beekeeping contributes to the national economy through foreign exchange profits. Ethiopia is one of the four largest wax exporters on the world market, with estimated 3200 tons of beeswax each year (the other three are China, Mexico, and Turkey).

Despite the fact that the country has a long history of beekeeping and is well adapted to supporting a high number of bee colonies, bees and plants they rely on are constantly endangered by a lack of understanding and respect for these endowments, as all are renewable natural resources [8]. Furthermore, in all sections of the country, several million colonies of bees are managed using traditional beekeeping methods. Traditional beehives are basic cylindrical containers in which bees and their combs are housed. They are hives with permanent honeycombs that are typically housed in hollow logs or clay or Wicken's vessels. Traditional beekeeping, unfortunately, does not use modern equipment and practices. As a result, collecting fruits and vegetables kills or seriously weakens the colony.

Over the last 20 years, there has been a tiny but continuous interest in modern hive beekeeping methods; farmers retain approximately 10,000 frame hives and 30,000 top bar hives [9]. Frame hives will only benefit if they are used effectively and in accordance with technology. Almost all of Africa's frame hives have been project-related in some form or kept by beekeeping hobbyists or enthusiasts, many of whom are expats.

However, in recent years, the well-known type of movable frame hive, the modern hive $(\mathrm{MH})$, has been introduced and enthusiastically promoted. It is a contemporary beekeeping technology that provides an alternative solution for people who employ frame hives. The key benefits of a moveable frame hive are that it is much more productive and easier to manage bee colonies than a regular hive, which requires others to be examined. Furthermore, it is easier to open, remove, and harvest than a regular hive.

In the study, woreda beekeeping is done with either a moveable frame or a contemporary frame, both under the same traditional management style. However, information on the characteristics that contribute to their adoption and productivity in actual field conditions is scarce. As a result, the research study is aimed at new beekeepers, particularly extension agents, who are responsible for offering technological alternatives that are appropriate to the goals and resources of beekeepers in the study area, as well as introducing beekeeping in areas where it is not currently practiced.

Furthermore, there is no research trying to discover the relevant socioeconomic characteristics in the adoption and economics of the introduced hive technologies. As a result, this study investigates the adoption of contemporary hive beekeeping technology versus old technology, as well as the variables that influence the acceptance of $\mathrm{MH}$ with its associated qualities in the selected areas, as specified in the background. The final product of the research study could be used by development petitioners, policymakers, and future researchers, among others. The conceptual framework for the study is depicted in Figure 1. Based on a review of the literature, it is hypothesized that personal attributes (age, family size, perception, experience, and so on), environmental factors (bee forage, diseases, and pests), institutional factors (credit, market, extension, and so on), and socioeconomic factors (income, total number of honeybee colonies, backyard size, and so on) influence technology adoption. According to Degnet et al. [10], the motivations for farm-level adoption vary in space and time. Adoption is influenced by factors that are neither wholly economic nor purely non-economic. Economic and non-economic factors are important in molding farmers' attitudes about new technology and its eventual acceptance.

\section{Materials and Methods}

2.1. Description of the Study Area. The Kembata Tembaro Zone is one of the highly populated zones in the Southern Nations, Nationalities, and People's region. The zone has 7 rural woredas (districts) and 2 administrative towns. KachaBirra is one of the woredas in the zone and has 21 rural kebeles and one administrative town. The district capital town Shinshicho is found $365 \mathrm{~km}$ from Addis Ababa and $144 \mathrm{~km}$ from the regional capital, Hawassa through Shashemene. The district lies between N07 17.83 and $\mathrm{N}^{\circ} 7^{\circ}$ $12^{\prime} 30.1^{\prime \prime}$ north latitude and E37 4704.8 and E037 50 '30.6" degree east longitude with altitude ranging from 1600-2800 ma sl [11]. The total area of the district is estimated to be $306 \mathrm{~km}^{2}$. The study area map for the study is depicted in Figure 2.

The woreda is divided into two agroecological zones: "Dega" (wet highland and comparatively chilly) and "Woina Dega" (moderately warm midland) with bimodal rainfall distributions "Belg" and "Kiremt." The rainfall season in the research area "Belg" is short, lasting from January to April. During this time, the area receives $150 \mathrm{~mm}$ of rain every month on average. The "Kiremt" season, on the other hand, is the longest period of rain between May and October, with a monthly average rainfall of approximately $205.2 \mathrm{~mm}$. There are only two livelihood zones in the woreda livelihood zone: Hadiya-Kembata enset and cereal zone; and Hadero ginger livelihood zone. The average lowest and maximum temperatures in the research area are $180 \mathrm{C}$ and $310 \mathrm{C}$, respectively [11].

According to [13], Kacha-Birra Woreda is one of the food insecure woredas due to recurring drought and failure 


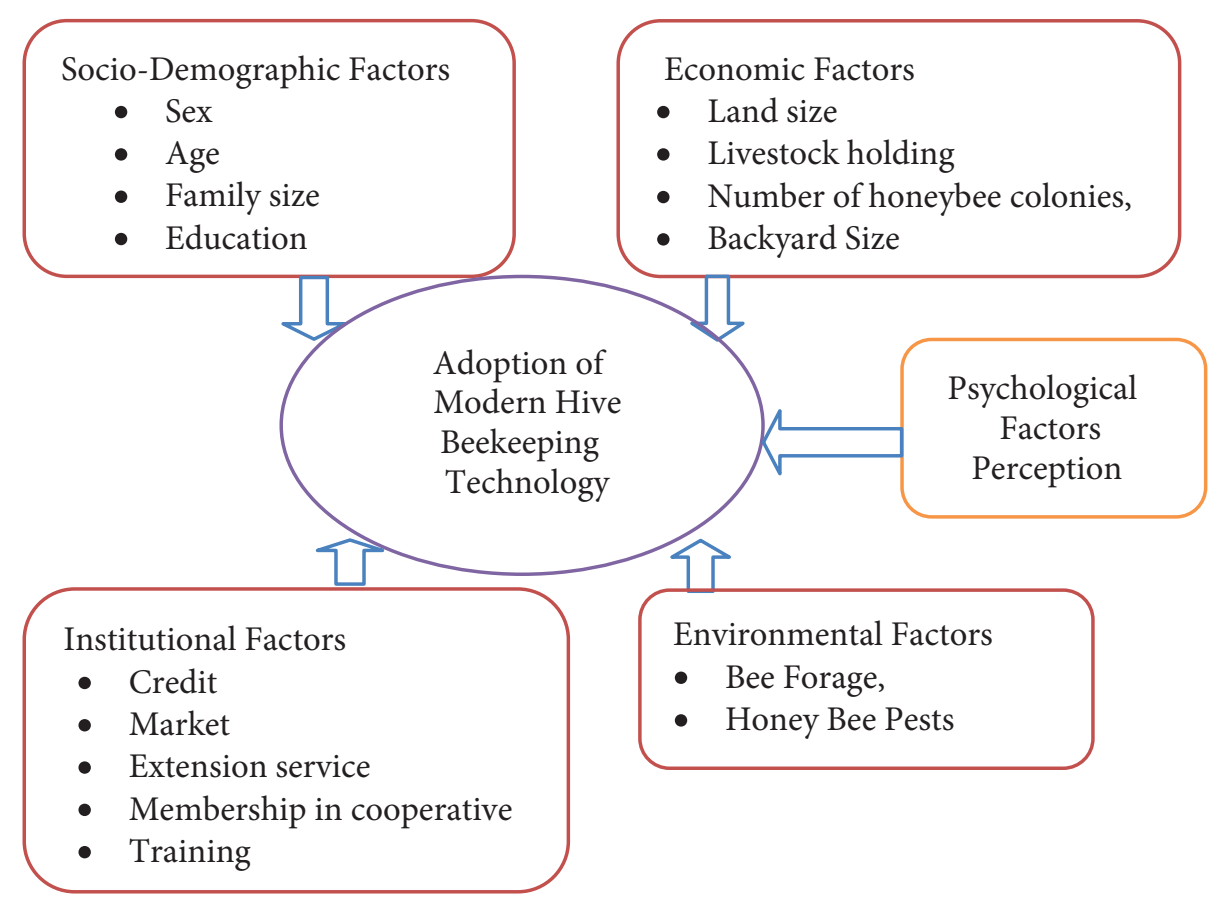

FIGURE 1: Conceptual framework of the study (source: on the basis of the available literature).

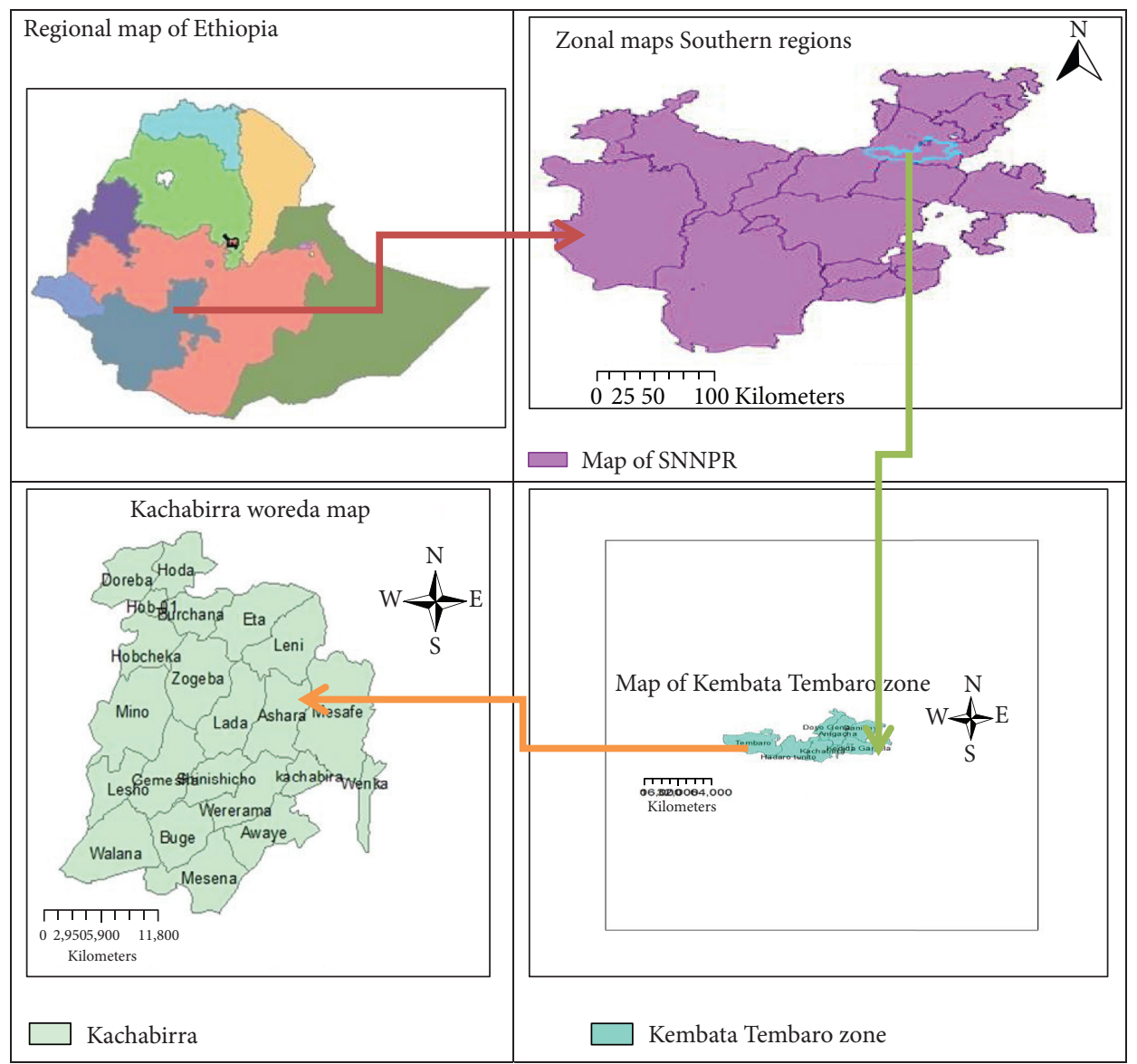

FIgURE 2: Map of the study area (source: Ethiopia GIS Version 10.1 software, 2014 [12]). 
of Belg production, which accounts for $23 \%$ of the woreda's total production. Other factors that contribute to food insecurity include a lack of farmland, high population density, reduction in soil fertility, and environmental deterioration. Households with insufficient land size, large family size, and a shortage of oxen were particularly vulnerable. The most vulnerable populations in both agroecology and human ecology were children, pregnant and breastfeeding mothers, the elderly, and female-headed families. Due to this, loans were distributed to farmers for different agricultural and non-agricultural activities through OMFI.

\subsection{Sampling Techniques}

2.2.1. Sample Size. The mathematical formula was used to determine the sample size. Yamane [14] proposed the following mathematical formula to calculate the sample size.

$$
\mathbf{n}=\frac{\mathbf{N}}{1+\mathrm{Ne}^{2}},
$$

where $N$ is the total number of rural farmers who have adopted improved hive beekeeping, and a confidence level of $90 \%$ was used. The error term would be 0.07 on the basis of this. The sample size was then calculated using the total population of 698 and an error margin of 0.07 .

$$
\mathbf{n}=\frac{698}{1+698(0.07)^{2}} .
$$

Assuming that $C_{1}$ is the total population of Ashira Kebele and $C_{2}$ is the population of Buge Kebele, when $C_{3}$ is the population of Gemesha Kebele and $C_{4}$ is the entire population of Walana Kebele, the sample size for each kebele was computed using proportional representation as follows:

$$
\mathrm{S}_{\mathbf{i}}=\frac{\mathrm{C}_{1} \mathbf{X S}_{\mathrm{t}}}{\mathrm{N}}
$$

where $S_{i}=$ sample size of each kebele, $C_{1}=$ total population of Ashira, $S_{t}=$ total sample size of the study area, and $N=$ total population of the study area. As a result, Ashira kebel $C 1=25$, Buge kebel $C 2=16$, Gemesh kebel $C 3=21$, and Walana kebel $C 4=27$. In this case, 89 is a proportional representation of the total population of 698 respondents for four kebeles and the number of respondents picked from each.

As a result, a sample size of 89 was picked from the overall population in Table 1 of 698 adoptions of modern hive beekeeping by rural farmers. A simple random sample procedure was used to determine the 89 participants.

2.2.2. Sampling Design and Procedure. In this investigation, both probability and non-probability sampling techniques were applied. It is based on the adoption of modern hive beekeeping among rural farmers in the Kacha-Birra Woreda of the SNNPR, which has seven rural woredas in the Kembata Tembaro Zone. The Kacha-Birra Woreda was chosen on purpose because the researcher lives in the woreda. Using simple random sampling, four kebeles were
TABLe 1: Total number of respondents and name of kebeles.

\begin{tabular}{lccccc}
\hline S. No. & Name of the kebeles & Total population & M & F & Total \\
\hline 1 & Ashira & 198 & 23 & 2 & 25 \\
2 & Buge & 130 & 14 & 2 & 16 \\
3 & Gemesha & 160 & 19 & 2 & 21 \\
4 & Walana & 210 & 24 & 3 & 27 \\
& Total & $\mathbf{6 9 8}$ & $\mathbf{8 0}$ & $\mathbf{9}$ & $\mathbf{8 9}$ \\
\hline
\end{tabular}

chosen, namely, Ashira, Buge, Gemesha, and Walana. In the rural area, there are a total of 698 communities. The woreda has 21 rural kebeles, modern hive beekeeping is practiced in 12 of them, and four kebeles would be chosen using a simple random selection technique. The number of samples for size sampling in each kebel was determined using a probability proportionate approach. The researcher used an interview schedule to collect quantitative data from 89 respondents.

2.3. Data Type and Sources. Primary data were acquired from sampled families depending on their level of adoption in different agroecological zones by interviewing households using prepared questionnaires. Furthermore, data were collected from secondary sources such as various government agencies, woreda reports and studies completed in the area, and development groups involved in livelihoods and development.

Quantitative data were collected from 89 sampled modern hive beekeeping farmers using an interview schedule, and FGD had eight innovative contemporary hive beekeeping farmers, as well as eight key informant DAs, bee experts, Kebel Administrative, Woreda Agricultural Office, and Community Elders, who were interviewed using a checklist.

2.4. Data Collection Techniques. The structured interview schedule was used to acquire primary data from sampled beekeeping producers. Secondary data were collected from secondary sources such as the government (BOARD, BOFED, and Administrative Office in 2015) $[15,16]$ and development organizations using an interview guide. Primary data were collected from district agriculture experts, kebele DAs, and model farmers through key informant interviews. The summary of qualitative data was analyzed by focus group discussion (FGD) and key informant interview (KII).

2.5. Methods of Data Analysis. Data analysis methods included descriptive statistics such as percentage, frequency, mean, and standard deviations; the $t$-test and $x^{2}$ were also used to test continuous and discrete variables, respectively. Any item that could not be quantified was qualitatively investigated qualitatively through interviews and group discussion with extension workers and beekeepers.

2.5.1. Chi-Square Test. The strength of this relationship is reflected in the chi-square statistic. The bigger the chi-square statistic, all else being equal, the stronger the relationship. 
The chi-square statistic is typically seen near the bottom of a contingency table.

The probability of the chi-square statistic indicates the likelihood that you would be mistaken if you asserted that there is a relationship between these two variables in the population from which you took your sample.

$$
x^{2}=\frac{\sum i \sum j(O i j-E i j) 2}{E i j},
$$

where $O=$ observed frequency and $E=$ expected frequency.

$$
E i i=\operatorname{column} \sum X \text { raw } \frac{\sum}{\text { grand } \sum} .
$$

Row $(r)$ cells that are attached horizontally are referred to as a row.

Column $(c)$ represents cells that are attached vertically and are referred to as a column.

Degrees of freedom: a number that you would use to find the critical value of a chi-square statistic using a chi-square table. The formula you use to compute a chi-square statistic is the following.

Degree of freedom $(\mathrm{df})=($ raw -1$) \times($ column -1$)$.

2.5.2. One-Sample t-Test. A one-sample $t$-test is a statistical tool used to investigate the mean difference between the sample and an unknown population mean value. We now know if the unknown population means significance or not in our one-sample $t$-test. The technique is as follows:

$$
\mathbf{t}=\frac{\bar{\Upsilon}-\boldsymbol{\mu}}{\mathbf{s . d} / \sqrt{\mathbf{n}}}
$$

where $t=t$ statistics, $\bar{\Upsilon}=$ sample mean, $\mu=$ population mean, s.d = standard deviation, and $n=$ sample size.

If there are $n$ observations in the sample and we are looking at a single mean, we utilize the $t$ distribution with $\mathrm{df}=n 1$ degrees of freedom.

A confidence interval for the population mean is the sample mean and corresponds to the confidence level and degrees of freedom, and SE is the standard error calculated by the sample, based on a sample of $n$ independent and nearly regular observations.

2.5.3. Two-Sample t-Test. This algorithm computes the sample size and power for one-sided or two-sided twosample $t$-tests where the variances of the two groups (populations) are assumed to be equal. This is the standard two-sample $t$-test.

The expected difference between means is defined in this method by providing the means for the two groups and letting the software calculate the difference. Use the twosample $t$-test assuming equal variance (homoscedastic) approach if you want to enter the difference directly.

The design of this test procedure is commonly referred to as a parallel group design. This design is used to compare the income levels of the two regions; there are numerous statistical tests available to compare the centers of the two populations.
This approach applies only to the two-sample $t$-test with equal variance.

$$
\mathbf{t}=\frac{\bar{\Upsilon}_{1}-\bar{\Upsilon}_{2}}{\sqrt{\left(\left(\left(\mathbf{n}_{1}-1\right) \mathbf{s}_{1}^{2}+\left(\mathbf{n}_{2}-1\right) \mathbf{s}_{2}^{2}\right) / \mathbf{n}_{1}+\mathbf{n}_{2}-2\right)\left(1 / \mathbf{n}_{1}+1 / \mathbf{n}_{2}\right)}} .
$$

This $t$-statistic follows a $t$-distribution with degrees of freedom $n_{1}+n_{2}-2$.

(1) Model Specification. Following Maddala [17] and Green [18], the logistic distribution for the adoption of modern hives can be specified as

$$
P_{i}=\frac{1}{\left(1 \pm e i^{-z i}\right)}
$$

where $P_{i}$ is a probability of adoption of a modern hive for the farmer, $e$ represents the base of natural logarithms, and $Z_{i}$ is the function of a vector of $n$ explanatory variables, which is expressed as $Z i=P o+\sum_{I=1}^{m} p i x i+U i$, where $Z$ is an underlying and unobserved stimulus index for the $i$ th farmer, ${ }_{i}$ are observations on variables for the adoption model, $P o$ is the constant term, $P_{i}$ are the unknown parameters to be estimated, $U_{i}$ is the disturbance term, and $m$ is the number of explanatory variables identified for the study.

If $p_{i}$ is the probability of adopting an improved box hive, $1-P_{i}$ represents the probability of not adopting the technology and is expressed as

$$
1-P i=1-\frac{1}{\left(1+e^{-z i}\right)}=\frac{1}{\left(1+e^{-z i}\right)} \cdot \frac{e^{-z i}}{\left(1+e^{-z i}\right)}=\frac{1}{\left(1+e^{-z i}\right)}
$$

Then, the odds ratio of equations (8) and (9) is expressed as

$$
\frac{P i}{1-P i}=\frac{1-e^{-z i}}{1+e^{-z i}}=e z i
$$

where $P i$ defines the probability of adoption of a modern hive to non-adoption of the technology. Finally, the logit model is expressed as follows by taking the natural logarithm of an odds ratio.

$$
\begin{array}{r}
L i=\ln \left[\frac{p i}{1-p i}\right]=\ln \\
e P o+\sum p i x i=z i=p o+\sum_{i=1} p i x i
\end{array}
$$

where $l i=\log$ of the odds ratio in favor of modern hive adoption, which is linear in $x i$ and linear in the parameters. Thus, if the stochastic disturbance term $(u i)$ is introduced, the logit model becomes the logit model.

$$
Z i=P o+P 1 x u+B 2 x 2+\cdots+B n x i+u i .
$$


(2). Estimation Procedure. Multicollinearity is verified before using the model to rule out one of the highly correlated explanatory variables. As a result, there is no significant multicollinearity (Appendices B and C). As a result, the variance inflation factor (VIF) for continuous variables and the contingency coefficient (CC) for dummy variables were tested.

The more significant the value of VIFi is, the more difficult it is to do. As a general rule, if the VIF of a variable exceeds 10 (as it will if $R i^{2}$ surpasses 0.95 ), VIFj is expressed as

$$
\operatorname{VIF}(\mathbf{X j})=\frac{1}{1-\mathbf{R j}^{2}},
$$

where $R j^{2}$ is the coefficient of determination when the variable $X j$ is regressed on the other explanatory variables, specified in Appendix C.

There may also be an interaction between qualitative variables, which can lead to the problem of multicollinearity. To detect this problem, the coefficients of contingency were compounded.

The contingency coefficient was compounded as follows.

$$
C=\sqrt{\frac{x^{2}}{n+x^{2}}}
$$

where $C$ is the coefficient of contingency, $x^{2}$ is chi-square test, and $n=$ total sample size.

To estimate the parameters of the models, iterative maximum likelihood (ML) estimation approaches are used. Maximum likelihood is the most effective (and, in some cases, the only) method for estimating the parameters of specification with a small number of dependent variables. In a broad sense, the ML approach produces values for unknown parameters that optimize the likelihood.

\subsection{Definitions of Variables and Working Hypotheses}

2.6.1. Dependent Variable. The dependent variable is described as "farmers' adoption of modern hive beekeeping technology," which was measured as a dummy variable with a value of 1 if the beekeepers embrace modern hive technology and a value of 0 if the beekeepers do not use modern hive technology.

2.6.2. Independent Variables. The variables hypothesized to be used in the analysis for "farmers' adoption of modern hive beekeeping technology" are significantly influenced by psychological, environmental, social, institutional, and economic factors, as shown in Table 2.

\section{(1) Socio-Econometric Factors}

(1) Sex of the respondents (sex): if the household head is male, this dummy variable returns 1 ; otherwise, it returns 0 . Gender differences in farm households played an important influence among farmers. As a result, this variable predicts that male farmers are more likely to be adequately productive than female farmers due to increased honey production.

(2) Age (AGE): it is a continuous variable that is measured by the number of completed years of life. According to the literature, young farmers are more adaptable to change than older folks (19). As a result, it was predicted that young farmers will adopt better hives more than seniors.

(3) Family size (FAMLSIZ): the total number of household members is a continuous variable that is measured. Farmers with large family sizes may be more likely to use technology to meet their family's needs. As a result, households with a large family were expected to be more likely to adopt technology.

(4) Education of the household head (EDUCATI): the acceptance and profitability of enhanced beekeeping hive technology requires technical applicability; Duze [20] observed that education improves decision making and hence influences the level and/or composition of other inputs. As a result, education would improve knowledge of the technology and is expected to promote adoption. As a result, this characteristic was expected to have a beneficial influence on adoption.

(2) Economic Factors

(5) Land size (LANDSIZE): the entire land area is owned by the farmers in the area. Land is measured in hectares and is extremely valuable to farmers. Farmers who have acquired asset ownership are more likely to receive service due to their larger cattle farm size, higher household income, higher level of market integration, greater usage of superior hive technology, and higher operating expenditures and investments. That is, it directly contributes to the adoption profitability of better hives, as it improves farmers' economic standing. Therefore, it is hypothesized that the land has a positive relation.

(6) Livestock holding of households (LIVESTOCK): the number of animals is an important proxy for assessing the respondent's wealth status in the research area. As a result, a favorable association was expected between high-vegetation farmers and improved hive beekeeping technology. As a result, the number of livestock was calculated in Tropical Livestock Units (Appendix A).

(7) Total number of honeybee colonies (BEECOLON): the total number of colonies of honeybees is used to calculate a continuous variable. Beekeepers with honeybee colonies were expected to accept the technique because it involves shifting honeybee colonies from ordinary hives to enhanced hives.

(3) Environment Factors

(8) Honeybee pests (PESTPRBLM): it is a dummy variable that was measured by assigning a value of 1 if the problems do not occur and a value of 0 
TABLE 2: Explanatory/independent variable.

\begin{tabular}{|c|c|c|c|}
\hline Independent variables & Variable type & Variable definition & Expected sign \\
\hline Sex & Dummy & Sex of household head in years & - \\
\hline AGE & Continuous & Age of household head & + \\
\hline FAMSIZE & Continuous & Number of household members & + \\
\hline EDUC & Continuous & Education of formal education years & + \\
\hline LANDSIZE & Continuous & Land size & + \\
\hline N H C & Continuous & Number of honey colonies & + \\
\hline TLUOWN & Continuous & Total live stock ownership & + \\
\hline ACCESS & Dummy & Access of credit & + \\
\hline MICOP & Dummy & Membership of honeybee association & + \\
\hline ACCM & Dummy & Access to market service & + \\
\hline EXSRV & Dummy & Extension service & + \\
\hline PERCP & Dummy & Perception of farmers & + \\
\hline TRAINING & Dummy & Number of training given & + \\
\hline BFLORA & Dummy & Bee flora & + \\
\hline HONEY PEST & Dummy & Honey pest & - \\
\hline
\end{tabular}

otherwise. The presence of honeybee diseases, pests, and predators has a significant impact on honeybees and, as a result, on hive products. As a result, it was anticipated that honeybee sickness, pests, and predators had a negative impact on the enhanced beekeeping technology in the research area.

(9) Bee forage: some farmers are influenced by traditional beekeeping methods to employ modern beekeeping. Environmental constraints, on the other hand, may prevent farmers from adopting modern hive technology. As a result, the availability of bee feed determined the degree to which modern hive beekeeping equipment was adopted.

(4) Institutional Factors

(10) Access to credit (CREDIT): it has been stated in the literature that lack of credit is a barrier to adoption. As a result, a lack of initial capital prevents farmers, particularly resource-poor farmers, from adopting low-tech solutions. It is a dummy variable that was measured with 1 if the respondent received credit from a credit institution and 0 otherwise. Obtaining and utilizing credit for intended purposes has been shown to boost the adoption of modern hive beekeeping technology; therefore, it was anticipated that receiving credit and better hive beekeeping technology would have a beneficial association.

(11) Beekeeping training (BKTRAIN): it is a dummy variable that was measured by assigning a value of 1 if the respondent has had beekeeping training and a value of 0 otherwise. Training is essential to raise awareness of the technology and increase the beneficiary's productivity. As a result, it was predicted that receiving training on the technology will have a favorable impact on better beekeeping of the technology.
(12) Extension contact (EXTCONTA): according to [21], extension activities increase the likelihood of new technology by increasing the store of information about the current production increments. It is a dummy variable that was measured by assigning a value of 1 if the beekeeper had contact with an extension agent and a value of 0 otherwise. The effective use of new hive beekeeping technologies requires close monitoring by extension workers. As a result, beekeepers who had an interaction with an extension agent were expected to be more likely to embrace the technique.

(13) Access of market for products (MKTAVAIL): markets for input and output are known to positively impact the adoption of improved beekeeping agriculture technologies. It is a dummy variable that was measured by assigning a value of 1 if the responder had a market for their goods and a value of 0 otherwise. The availability of a market for hive products influences the decision to enhance technology. As a result, it was predicted that there would be a beneficial relationship between the market and the adoption of enhanced hive beekeeping technologies.

(14) Membership in the cooperative (MEBCOOP): household cooperatives have more access to agricultural institutions' technology. Cooperative membership allows the respondent to exchange ideas, experiences, and skills. Cooperative memberships have a beneficial association.

(5) Psychological Factors

(15) Farmer perception (FPER): farmers' perceptions of innovation characteristics determine the rate of adoption and profitability of improved hive beekeeping. The perceived relative advantages and disadvantages of improved hive 
beekeeping were measured using Likert fivepoint measures. It was expected that the sum of perceived qualities (advantages and downsides of the technology) favorably influences the adoption and profitability of improved hive beekeeping.

\section{Results and Discussion}

3.1. Adoption of Modern Hive Beekeeping Technology Status of the Sample Respondents. According to secondary research, only a small percentage of farmers in the woreda are using contemporary beekeeping technology. As a result, woreda farmers have received significant technology from many institutions, with the majority of farmers coming from agricultural institutions. As a result, in the research region, farmers have implemented modern hive beekeeping technology and agricultural activities, both for agricultural productivity and revenue producing activities, which are measured to know the farmers who have adopted modern hive beekeeping technology. According to data from the research area, around $37 \%$ of the sampled farmers were adopters, whereas $63 \%$ were nonadopters.

\subsection{Determinants of Adopting Modern Hive Beekeeping} Technology. The introduction of new technology to smallholder farmers does not ensure widespread adoption and efficient use of technology. Farmers' adoption decisions are influenced by a variety of factors. Farmers' decisions to accept agricultural innovations can be influenced by factors related to their economic, institutional, demographic, and physical qualities. In their research report [22], Udimal et al. said that credit, farm size, risk, labor availability, human capital, land tenure, and education are the most important factors influencing technological adoption. Characteristics identified as having a relationship with adoption are classified as personal, economic, institutional, and intervening (psychological) factors in the household for convenience of grouping [23].

3.2.1. Socio-Demographic Factors. The sociodemographic parameters of this study include gender, age, household family size, and education level in relation to current hive beekeeping technology.

(1) Sex of the Household Head. One of the factors that distinguishes the adoption of modern hive beekeeping technology is the gender of the household head. As a result, it was postulated that the gender of the head of household has a negative relationship with the state of adoption of modern beekeeping equipment.

There were $10.1 \%$ of female-headed households and $89.9 \%$ of male-headed households among the total sampled 89 households, according to Table 3. According to the data poll, $2.2 \%$ of female-headed families adopted modern beehive beekeeping equipment, while $7.9 \%$ did not. As a result, the Pearson chi-square value (0.947) suggests that there is no statistically significant relationship between the gender of the respondents and the status of adoption of modern beekeeping technology.

(2) Age of Household Head. One of the factors that influence the adoption of current hive beekeeping technologies by respondents is their age. Age influences the adoption of modern hive beekeeping technology by sampled home respondents, as hypothesized by the factors. According to Table $4,84.3 \%$ of the respondents are between the ages of 25 and 60 . The respondents' average age is 45.75, with a minimum age of 25 and a maximum age of 78 . According to the data, the majority of the respondents sampled are in the productive age range. In this survey, $36 \%$ of the total respondents were users of current hive beekeeping technology, which they discovered in productive age. The remaining $48.3 \%$ did not use modern hive beekeeping techniques. As a result, the $t$-value (1.941) suggests that there is a statistically significant difference between the age of the household respondents and their use of current hive beekeeping technologies. According to Bekuma [24], age is an essential family feature that determines the adoption behavior of subsistence farmers. It is commonly assumed that older farmers will have greater expertise and skills in agriculture, allowing them to quickly appreciate the benefits of technology better than others. According to Gebiso [25], the increase in the adoption of technology with age may be related to the fact that most resources are in the hands of older people and most young farmers do not have enough back yards to beekeeping and live in a town in most situations.

(3) Family Size of the Sample Households. The family size and adoption of current hive technologies were anticipated to be well associated. The majority of responders with a large family are non-adopters of technology. The family sizes of the respondents were divided into three categories. According to Table 5, respondents with family sizes of 2-4, $5-7$, and $>7$ are $34.8 \%, 52.8 \%$, and $12.4 \%$, respectively. The average family size of the respondents was 5.33 , with a standard deviation of 1.79 . The respondents' average family size was two people, with a maximum of nine people per household head. Furthermore, this chart shows that the majority of respondents, $20.2 \%$, used modern hive beekeeping technology while $32.6 \%$ of non-adopters used a range of 5-7. As a result, the computed $t$-value (1.136) does not show statistically significant difference between family size and use of modern hive beekeeping techniques. Farmers with large families may be more likely to utilize technology to meet their family's needs. As a result, it was assumed that households with a big family would be more likely to accept technology. This suggests that beekeepers with a big family size prefer to invest in better technology in order to increase output and income. Adopting improved box hives necessitates more labor; therefore households with larger families are better equipped to meet these needs (IPMS, 2005). The most labor-intensive tasks include beehive construction, honey extraction, and colony multiplication (IPMS, 2005). 
TABLE 3: Sex distribution of the household head.

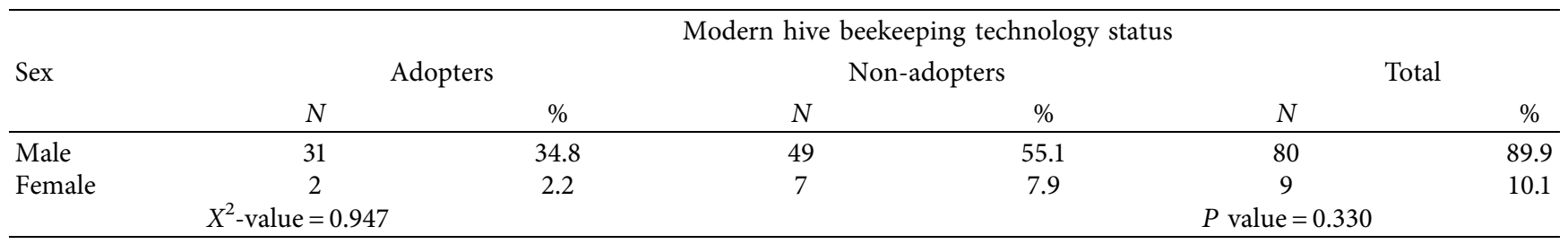

Source: own survey data, 2016.

Table 4: Age of the household head.

\begin{tabular}{|c|c|c|c|c|c|c|}
\hline \multirow{3}{*}{ Age } & \multicolumn{6}{|c|}{ Modern hive beekeeping technology status } \\
\hline & \multicolumn{2}{|c|}{ Adopters } & \multicolumn{2}{|c|}{ Non-adopters } & \multicolumn{2}{|c|}{ Total } \\
\hline & $N$ & $\%$ & $N$ & $\%$ & $N$ & $\%$ \\
\hline $25-40$ & 16 & 18 & 20 & 22.5 & 36 & 40.5 \\
\hline $41-60$ & 16 & 18 & 23 & 25.8 & 39 & 43.8 \\
\hline$>60$ & 1 & 1.1 & 13 & 14.6 & 14 & 15.7 \\
\hline Mean & 42.45 & & 47.70 & & 45.75 & \\
\hline SD & 9.32 & & 13.75 & & 12.50 & \\
\hline Minimum & 25 & & & & & \\
\hline Maximum & 78 & & & & & \\
\hline$t$-Val & $=1.941$ & & & valt & $0.055^{*}$ & \\
\hline
\end{tabular}

*Significant at $10 \%$ probability level (source: own survey data, 2016).

TABLE 5: Distribution of the family size of the household of the respondents.

\begin{tabular}{lcccccc}
\hline & \multicolumn{3}{c}{ Modern hive beekeeping technology status } \\
Family size & \multicolumn{2}{c}{ Adopters } & \multicolumn{2}{c}{$\begin{array}{c}\text { Non- } \\
\text { adopters }\end{array}$} & \multicolumn{2}{c}{ Total } \\
& $N$ & $\%$ & $N$ & $\%$ & $N$ & $\%$ \\
\hline $2-4$ & 10 & 11.2 & 21 & 23.6 & 31 & 34.8 \\
$5-7$ & 18 & 20.2 & 29 & 32.6 & 47 & 52.8 \\
$>7$ & 5 & 5.6 & 6 & 6.7 & 11 & 12.4 \\
Mean & 5.61 & & 5.16 & & 5.33 & \\
SD & 1.78 & & 1.79 & & 1.79 & \\
Minimum & 2 & & & & & \\
Maximum & 9 & & & & & \\
\multicolumn{1}{c}{$\boldsymbol{t}$-Value $=\mathbf{1 . 1 3 6}$} & & & & \\
\end{tabular}

Source: own survey data, 2016.

(4) Education Level of Sampled Household Head. The amount of education affects the level of information and technology transfer, which affects individual productivity; it is closely related to the acceptance by the household of the consumption of modern beehive technology. The use of modern hive beekeeping technologies was expected to have a favorable relationship with this characteristic [27]. It can assist them in comprehending the advantages of technology. However, a lack of education and a low level of awareness make it difficult to handle and use technology. According to the poll results in Table $6,83.1 \%$ of the total respondents are literate (attending grade 1 and above), 37.1\% are adopters of current hive technology, and $16.9 \%$ are illiterate. As a result, literate respondents are more likely than illiterate respondents to adopt modern hive technology. As a result,
TABle 6: Distribution of the level of education of the respondents.

\begin{tabular}{|c|c|c|c|c|c|c|}
\hline \multirow{3}{*}{ Educational level } & \multicolumn{6}{|c|}{$\begin{array}{c}\text { Modern hive beekeeping technology } \\
\text { status }\end{array}$} \\
\hline & \multicolumn{2}{|c|}{ Adopters } & \multicolumn{2}{|c|}{$\begin{array}{l}\text { Non- } \\
\text { adopters }\end{array}$} & \multicolumn{2}{|c|}{ Total } \\
\hline & $N$ & $\%$ & $N$ & $\%$ & $N$ & $\%$ \\
\hline Unable to read and write & 0 & 0 & 15 & 16.9 & 15 & 16.9 \\
\hline From grades $1-4$ & 8 & 9 & 21 & 23.6 & 29 & 32.6 \\
\hline From grades $5-8$ & 21 & 23.6 & 19 & 21.3 & 40 & 44.9 \\
\hline$>$ grade 8 & 4 & 4.5 & 1 & 1.1 & 5 & 5.6 \\
\hline Mean & 6.2 & & 3.5 & & 4.5 & \\
\hline $\mathrm{SD}$ & 2.29 & & 2.75 & & 2.91 & \\
\hline Mini & 0 & & & & & \\
\hline & 12 & & & & & \\
\hline \multicolumn{3}{|c|}{$t$-Value $=4.883$} & \multicolumn{4}{|c|}{$P$ value $=P \leq 0.001^{* * *}$} \\
\hline
\end{tabular}

*** Significant at $1 \%$ probability level (source: own survey data, 2016).

the $t$-value (4.883) indicates that there is a statistically significant difference between the level of education of the respondents and the state of use of modern hive beekeeping technology by responders. Tesfaye et al. [28] discovered that education level influenced the adoption of better wheat varieties and chemical fertilizers. Improved box hive technology utilization necessitates technical applicability; Usman [29] observed that education improves decision making and thus influences the level and/or composition of other inputs. As a result, education is expected to improve knowledge about technology and enhance adoption. Literate farmers are more exposed to the outside environment and knowledge, making it easier for them to connect with technological sources [30]. Similarly, the degree of education and the acceptance of new technology have a strong and direct relationship [31, 32].

\subsubsection{Economic Factors}

(1) Land Size. The size of landholding has an important impact on the adoption of current beehive technologies. In this study, all farm households examined had land; however, the extent of the land varied from respondent to respondent [33]. According to Table 7, the minimum and maximum landholdings are 0.20 and 1.25 ha, respectively. Farmers with land sizes ranging from 0.20 to 0.5 ha accounted for $64.1 \%$, with $27 \%$ adopter respondents and $37.1 \%$ non-adopter households, followed by $0.51-0.75$ ha at $21.3 \%$, with $5.6 \%$ adopter respondents and $15.7 \%$ non-adopter households, 
TABLE 7: Distribution of household respondents by land size.

\begin{tabular}{lcccccc}
\hline & \multicolumn{3}{c}{ Modern hive beekeeping technology status } \\
Land size (ha) & Adopters & \multicolumn{2}{c}{$\begin{array}{c}\text { Non- } \\
\text { adopters }\end{array}$} & \multicolumn{2}{c}{ Total } \\
& $N$ & $\%$ & $N$ & $\%$ & $N$ & $\%$ \\
\hline $0.2-0.5$ & 24 & 27 & 33 & 37.1 & 57 & 64.1 \\
$0.51-0.75$ & 5 & 5.6 & 14 & 15.7 & 19 & 21.3 \\
$>0.75$ & 4 & 4.5 & 9 & 10.1 & 13 & 14.6 \\
Mean & 0.50 & & 0.54 & & 0.53 & \\
SD & 0.28 & & 0.26 & & 0.26 & \\
Minimum & 0.20 & & & & & \\
Maximum & 1.25 & & & & \\
\multicolumn{1}{c}{$\boldsymbol{t}$-Value $=\mathbf{0 . 7 0 8}$} & & & & & \\
\end{tabular}

Source: own survey data, 2016.

and $>7.5$ ha at $14.6 \%$, with $4.5 \%$ adopter households. The average land size of respondents who are adopters and nonadopters is 0.50 ha and 0.54 ha, respectively. The $t$-value (0.708) indicates that there is no statistically significant difference between land size and the use of modern hive beekeeping technologies. This study supports Bekuma's [24] finding that land-related characteristics influence farmers' adoption behavior, as land ownership is an important unit where agricultural operations occur. Many adoption studies found that the size of the farm was strongly related to the adoption of improved technology [34, 35].

(2) Livestock Ownership of the Respondents. Livestock can be used as a source of cash income as well as a kind of savings. As a result, the amount of livestock owned by the household respondents and the use of modern hive beekeeping equipment were projected to be directly associated [36]. According to the results of the survey in Table 8, the average size of a livestock holding is about 3.02 TLU, with a range of 1 to 6 TLU. The majority of respondents' livestock holdings (58.4\%) are from 1-3 TLU. Approximately $22.5 \%$ of households in the adopter category have livestock holdings ranging from 1 to 3 TLU. The $t$-value of the survey result (0.566) suggests that there is no statistically significant difference between the holding of household livestock and the adoption of contemporary hive beekeeping techniques. This conclusion does not corroborate the findings of the Bekuma's report [24], as it affects the adoption of enhanced technologies differently by different people in different places, and it also has a positive contribution to the adoption of agricultural technology by households in most situations [23]. Many adoption studies found that cattle ownership has a beneficial effect on adoption $[34,37,38]$.

(3) Colony Number of Sampled Respondents. Honeybee colonies in the tested houses could benefit from current hive technologies [33]. As seen in Table 9, families with a higher number of colonies adopt technology more than those with a lower number of colonies. Adopter and nonadopter households have a mean of 4.18 and 2.41 children, respectively. The $t$-value (5.542) suggests a statistically significant substantial difference between colony count and the use of modern beekeeping technologies in hives.
TABLE 8: Distribution of household respondents by livestock holding.

\begin{tabular}{lcccccc}
\hline & \multicolumn{3}{c}{ Modern hive beekeeping technology status } \\
TLU & Adopters & \multicolumn{2}{c}{$\begin{array}{c}\text { Non- } \\
\text { adopters }\end{array}$} & \multicolumn{2}{c}{ Total } \\
& $N$ & $\%$ & $N$ & $\%$ & $N$ & $\%$ \\
\hline $1-3$ & 20 & 22.5 & 32 & 36 & 52 & 58.4 \\
$3.01-5$ & 8 & 9 & 19 & 21.3 & 27 & 30.3 \\
$>5$ & 5 & 5.6 & 5 & 5.6 & 10 & 11.2 \\
Mean & 2.89 & & 3.09 & & 3.02 & \\
SD & 1.72 & & 1.48 & & 1.57 & \\
Minimum & 1 & & & & & \\
Maximum & 6 & & & & \\
\multicolumn{1}{c}{$\boldsymbol{t}$-Value $=\mathbf{0 . 5 6 6}$} & $\mathbf{0 . 5}=\mathbf{0 . 5 7 3}$ & \\
\hline
\end{tabular}

Source: own survey data, 2016.

TABLE 9: Distribution of respondents by number of colonies.

\begin{tabular}{|c|c|c|c|c|c|c|}
\hline \multirow{3}{*}{ Number of colonies } & \multicolumn{6}{|c|}{$\begin{array}{c}\text { Modern hive beekeeping technology } \\
\text { status }\end{array}$} \\
\hline & \multicolumn{2}{|c|}{ Adopters } & \multicolumn{2}{|c|}{$\begin{array}{l}\text { Non- } \\
\text { adopters }\end{array}$} & \multicolumn{2}{|c|}{ Total } \\
\hline & $N$ & $\%$ & $N$ & $\%$ & $N$ & $\%$ \\
\hline $1-2$ & 5 & 5.6 & 35 & 39.3 & 40 & 44.9 \\
\hline $3-5$ & 22 & 24.7 & 19 & 21.3 & 41 & 46.1 \\
\hline$>5$ & 18 & 6.7 & 3 & 2.2 & 21 & \\
\hline Mear & 4.18 & & 2.41 & & 3.07 & 9 \\
\hline $\mathrm{SD}$ & 1.42 & & 1.47 & & 1.68 & \\
\hline Minimum & 1 & & & & & \\
\hline Maximum & 6 & & \multirow{2}{*}{\multicolumn{4}{|c|}{$P \leq 0.001^{* * *}$}} \\
\hline \multicolumn{3}{|c|}{$t-$ Value $=-5.542$} & & & & \\
\hline
\end{tabular}

${ }^{* * *}$ Significant at $1 \%$ probability level (source: own survey data, 2016).

Moreover, respondents' reported that as the number of colonies grows, so does the possibility of adopting modern hive beekeeping technology during the study period. This demonstrates that sample households with a greater number of colonies are actively participating in modern hive beekeeping technology due to the involvement of their resources in adopting technology in the research area. As a result, these data support Bekuma's findings [24] who claims that the introduction of upgraded hives and working instruments to the rural population is beyond the reach of farmers and they are difficult to obtain even for those who can afford it [39]. It should be assured that the new technology and all other relevant inputs are available on small holdings at the correct time and location, in the right quantity and quality [40]. The lack of capital and the lack of modern beehives and their accessories (honey harvesting and processing equipment such as wax stumpers, queen excluders, honey extractors, bee smokers, and others) around beekeepers are also big issues [25]. To handle a hive containing a honey bee colony, beekeepers must wear protective clothing (overall suit, bee veil, and gloves) and use equipment such as a smoker. The availability of the aforementioned materials determines the acceptance of the technology [23]. 
TABLE 10: Extension contact of beekeepers by agricultural experts.

\begin{tabular}{|c|c|c|c|c|c|c|}
\hline \multirow{3}{*}{ Extension contact } & \multicolumn{6}{|c|}{ Modern hive beekeeping technology status } \\
\hline & \multicolumn{2}{|c|}{ Adopters } & \multicolumn{2}{|c|}{ Non-adopters } & \multicolumn{2}{|c|}{ Total } \\
\hline & $N$ & $\%$ & $N$ & $\%$ & $N$ & $\%$ \\
\hline Contacted & 24 & 27 & 3 & 3.3 & 30 & 30.3 \\
\hline Not contacted & 9 & $\begin{array}{c}10.1 \\
\mathbf{X}^{2} \text {-va }\end{array}$ & $\begin{array}{c}53 \\
\leq 0 \\
\end{array}$ & 59.6 & 62 & 69.7 \\
\hline
\end{tabular}

*** Significant at $1 \%$ probability level (source: own survey data, 2016).

\subsubsection{Institutional Factors}

(1) Extension Contact with Agricultural Experts. Expert extension contact influences the adoption of modern hive beekeeping technology by responders. Timely extension contact with an expert is critical to ensuring the efficient use of the technology [41]. This extension contact helps the beekeeper in properly managing his/her productivity and, as a result, promotes the proper exploitation of honey products. According to the poll results in Table 10, extended contact with beekeepers was considered necessary before adopting the technology. According to the total number of beekeepers, $69.7 \%$ of the sample households reported that experts for technology adoption did not contact them, while $30.3 \%$ reported that experts do contact them. According to the findings, $27 \%$ of respondents used modern hive beekeeping technology, while $3.3 \%$ of non-adopters were supervised. As a result of the findings, extended contact prior to the deployment of current hive technology is critical to guaranteeing the efficient adoption of technology by the respondents. The $x^{2}$-value (44.593) indicates a statistically significant relationship between the extension contact of specialists and the status of modern hive beekeeping technology by responders. This finding is consistent with the findings of the Bekuma [24], since extension provides farmers with information on agricultural technology. Feder et al. [42] observed that expansion efforts improve the likelihood of new technology by increasing the store of information about the current production increment. The effective use of improved box hive technology requires close monitoring by extension workers. Many adoption studies have found that farmers who have access to extension services are more likely to embrace advanced agricultural technologies $[43,44]$.

(2) Training with Modern Beehive Technology. Beekeepers can improve their abilities and knowledge through training. A typical training course will most likely involve demonstrations and trips to beekeepers' areas where the technology has been used correctly [45]. According to the poll results in Table 11,39.3\% of respondents said that they have received training on technology adoption. The remaining $60.7 \%$ of the respondents responded that they had not been trained. The $x^{2}$-value (1.844) suggested that there was no statistically significant relationship between training and the adoption of contemporary beekeeping technology. This discovery does not support. According to Bekuma [24], training is critical to raising technology awareness and making beneficiaries more productive. According to Rahman [46], training may have instilled technical competencies, increased exposure to the subject matter, and persuaded farmers to adopt improved agriculture technologies. Beekeeper participation in the display and training of modern beehives was one of the most important predictors of acceptance [25]. Farmer training in technology, in this case the current beehive technology, had a beneficial impact on adoption because the proportion of taught adopters was much higher than the proportion of untrained adopters [47]. The acquisition of technical skills and knowledge of bee farming through training was likely to positively influence farmers' adoption decisions [48].

(3) Credit Access of the Respondents. Credit availability influences the adoption by respondents of the modern hive beekeeping technology status. Farmers who have access to loans can employ relevant technology. The remainder did not obtain credit $[49,50]$. In this study, the Pearson chisquare value of 3.576 demonstrated a statistically significant relationship between credit access and the state of adoption of modern hive beekeeping technology by responders. As a result, the more the finance available to beekeepers, the greater their chances of adopting technology (Table 12). This finding supports Bekuma's [24] findings. Farmers who engage in off-farm/non-farm businesses will have access to inputs such as modern beehive equipment. As a result, credit has a beneficial and considerable impact on the adoption of current beehive technology [51].

(4) Market Access of the Respondents. The market is large enough to encourage beekeepers to use current hive beekeeping technology. As a result, the market was predicted to be an element influencing the adoption of modern hive beekeeping equipment by households $[49,50]$. Respondents with no market access in the research area are opposed to technology adoption. According to the survey results in Table 13, of $39.3 \%$ of the sampled household respondents, $19.1 \%$ are early adopters of technology with market access, followed by $60.7 \%$ of selected households. $18 \%$ of the respondents are early adopters of technology with no market access. This suggests that the market is one of the most important institutional elements influencing technological adoption. As a result, the $x^{2}$-value (3.266) in this study reveals a statistically significant relationship between market access and the adoption of modern hive beekeeping technologies. This means that beekeepers who have access to markets to sell honey products are more likely to employ technology than those who do not. This finding is consistent with the findings 
TABLE 15: Distribution of perception of respondents.

\begin{tabular}{|c|c|c|c|c|c|c|}
\hline \multirow{3}{*}{ Perception } & \multicolumn{6}{|c|}{ Modern hive beekeeping technology status } \\
\hline & \multicolumn{2}{|c|}{ Adopters } & \multicolumn{2}{|c|}{ Non-adopters } & \multicolumn{2}{|c|}{ Total } \\
\hline & $\mathrm{N}$ & $\%$ & $N$ & $\%$ & $N$ & $\%$ \\
\hline Yes & 19 & 21.3 & 5 & 5.6 & 24 & 27 \\
\hline No & 14 & 15.7 & 51 & 57.3 & 65 & 73 \\
\hline & & & $P \leq$ & & & \\
\hline
\end{tabular}

*** Significant at $1 \%$ probability level (source: own survey data, 2016).

negative attitude toward technology. This suggests that perception is one of the most important psychological elements influencing technology adoption [59]. As a result, in this study, Table 15 shows that the $x^{2}$-value (24.951) reveals a statistically significant correlation between the perception of the respondents and the use of current beekeeping equipment in the hive. This means that beekeepers who have a good opinion of technology adoption are more likely to gain from it than those who do not. This discovery is beneficial. According to Bekuma [24], the rate of adoption is determined by farmers' perceptions of the attributes of the invention [60]. The positive perception of technology among beekeepers influences their decision to embrace it. Furthermore, respondents' perceptions of technological features are influenced by (I) awareness of relative advantages and (II) awareness of or concern about downsides, as well as the attribute of innovation. The difference between the two is then considered as the package's overall perceived attribute. The disparities between the two are then taken as the total perceived characteristic of the package [23,34], and this conclusion is consistent with the findings of Yehuala et al. [51] and Affognon et al. [61] who discovered that perception determines the adoption of beekeeping technology.

\subsubsection{Environmental Factors}

(1) Bee Forage. Some farmers are influenced by traditional beekeeping methods to employ modern beekeeping. Environmental constraints, on the other hand, may prevent farmers from adopting modern hive technology. The availability of bee food determined the degree to which modern hive beekeeping technology was adopted, and this is also suggested by the study of Andaregie and Astatkie [27]. Figure 3 shows how the foraging status of bees is classified for modern hive adoption.

According to the poll results, around $33.7 \%$ of the respondents were adopters of current hive technology, while the remaining $44.9 \%$ were non-adopters. As a result, the $x^{2}$ value (4.693) in this study reveals a statistically significant relationship between bee foraging and the adoption of modern hive beekeeping equipment. This means that sufficient bee feed encourages farmers to use modern hive beekeeping technologies in a suitable way because it reduces forage expenditure. This finding is consistent with [62].

(2) Honey Pests. Many farmers do not employ current hive beekeeping technology for a variety of reasons, according to evidence. Pest intervention in the beekeeping region was one

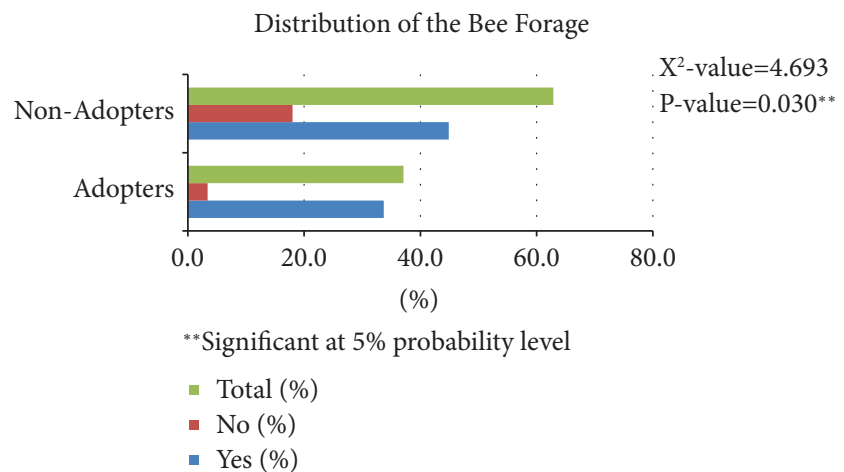

FIGURE 3: Distribution of the bee forage status (source: own survey data, 2016). ${ }^{* *}$ Significant at 5\% probability level.

of the elements that influenced the development of modern hive technology; the same is the true finding of Sahle et al. [7]. According to Figure 4, 29.2\% of the respondents did not use current hive beekeeping technology. The fundamental reason is that pests divert farmers' attention away from optimal technology use. As a result, the $x^{2}$-value (3.193) in this study reveals a statistically significant relationship between pest interference and the adoption of current hive beekeeping technologies. This implies that as pest interference increases, the probability of adoption of modern hive beekeeping technology decreases. This result supports the findings of FAO [63]; Monga and Manocha [53]; Gidey et al. [64]; Dabessa and Belay [65]; and Kiros and Tsegay [66].

\subsection{Summary of $t$-Test and $\chi^{2}$-Test for Continuous and Categorical Variables}

3.3.1. Summary of $\chi^{2}$-Value for Categorical Variables. Table 16 shows the summary of $\chi^{2}$-test values for categorical variables.

3.3.2. Summary of t-Test Values for Continuous Variables. Table 17 shows the summary of $t$-test values for continuous variables.

3.4. Logit Estimate Factors Affecting Adoption of Modern Hive Beekeeping Technology by Farmers. Tables 16 and 17 reveal that there was no problem with multicollinearity; since contingency coefficient and variance inflation factor were used to assess both continuous and categorical variables, 5 continuous and 10 categorical variables with a total of 15 


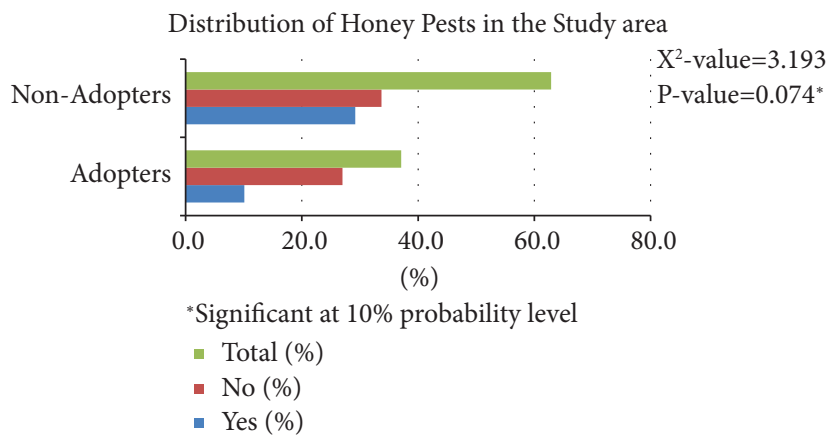

FIgURE 4: Distribution of honey pests in this study area (source: own survey data, 2016). * Significant at $10 \%$ probability level.

TABLE 16: Summary of $\chi^{2}$-test values for categorical variables.

\begin{tabular}{lcc}
\hline Variables & $\chi^{2}$-value & $P$ value \\
\hline Sex of household head & 0.391 & 0.532 \\
Extension contact & 44.593 & $\leq 0.001$ \\
Training & 1.844 & 0.174 \\
Credit access & 3.576 & 0.070 \\
Market access & 3.266 & 0.078 \\
Membership in coop & 0.233 & 0.644 \\
Perception of respondent & 24.951 & $P \leq 0.001$ \\
Bee forage & 4.693 & 0.030 \\
Honey pests & 3.193 & 0.074 \\
\hline
\end{tabular}

TABLE 17: Summary of $t$-test values for continuous variables.

\begin{tabular}{lcccc}
\hline Variables & Mean & SD & $t$-Value & $P$ value \\
\hline Age of household head & 42.45 & 9.32 & 1.941 & 0.055 \\
Family size of the sampled households & 5.61 & 1.78 & 1.136 & 0.259 \\
Educational level of the respondents & 6.2 & 2.29 & 4.883 & 0.708 \\
Total land size & 0.50 & 0.28 & 0.566 & 0.481 \\
Livestock ownership & 2.89 & 1.72 & -5.542 & 0.573 \\
Colonies amount & 4.18 & 1.42 & $0.001^{* * *}$ \\
\hline
\end{tabular}

${ }_{* * *},{ }^{* *}$, and ${ }^{*}$ indicate significance at probability levels of $1 \%, 5 \%$, and $10 \%$, respectively.

TABLE 18: Model estimates for factors affecting the level of adoption of modern beekeeping technology by farmers.

\begin{tabular}{|c|c|c|c|c|c|}
\hline Variables & Estimated coefficients $(\beta)$ & Std. error (S.E) & Wald & Sig. & $\operatorname{Exp}(B)$ \\
\hline SEX-AG & 2.437 & 2.138 & 1.299 & 0.254 & 11.438 \\
\hline Age of-AG & -0.144 & 0.125 & 1.335 & 0.248 & 0.866 \\
\hline Family size & -0.315 & 0.573 & 0.301 & 0.583 & 0.730 \\
\hline Education & 0.773 & 0.416 & 3.442 & $0.064^{*}$ & 2.165 \\
\hline Land size & -6.175 & 3.582 & 2.971 & $\mathbf{0 . 0 8 5}^{*}$ & 0.002 \\
\hline Livestock & -0.525 & 0.483 & 1.183 & 0.277 & 0.592 \\
\hline Colonies & 0.983 & 0.619 & 2.518 & 0.113 & 2.672 \\
\hline Extension contact & 4.108 & 2.310 & 3.163 & $0.075^{*}$ & 60.848 \\
\hline Training & 1.997 & 1.596 & 1.566 & 0.211 & 7.364 \\
\hline Credit & 4.756 & 2.294 & 4.297 & $\mathbf{0 . 0 3 8 ^ { * * }}$ & 116.261 \\
\hline Market & 4.065 & 1.867 & 4.743 & $0.029^{* *}$ & 58.288 \\
\hline Pests & -1.960 & 1.430 & 1.877 & 0.171 & 0.141 \\
\hline Constant & -2.638 & 4.380 & 0.363 & 0.547 & 0.072 \\
\hline
\end{tabular}

Pearson $X^{2}$ value: $95.29^{* * *}$, 2Loglikelihood 22.077. Correctly predicted percentage of adopters $=93.9$; correctly predicted percentage of nonadopters $=96.4$; overall percentage $=95.5$; sample size of respondents $=89 ;{ }^{* *}$ and ${ }^{*}$ significant at the probability level of $5 \%$ and $10 \%$ (source: computed from own survey data, 2016). 
variables, of which 12 variables were entered into the logistic regression estimates and the remaining three variables, such as perception, membership in cooperatives, and bee forage, were not entered into the log regression estimates due to $t$. The VIF values for five continuous variables were determined to be minimal (i.e. VIF values less than 10) indicating that the data does not have a major multi-collinearity problem. Table 18 shows the results of the logit analysis. The results of the logit analysis are displayed in Table 18.

3.4.1. Significant Explanatory Variables in the Logit Model. Table 18 shows the outcome of the logistic regression model. Five of the 15 explanatory variables expected to influence the adoption of modern hive beekeeping technologies in the research area were found to have an impact. The education of the households who responded, the size of the land, the extension, contact, the credit, and the access to the market are among them. As a result, important variables are examined further.

(1) Education of Household Respondents. The research study found that the education of the respondents' households in adopting modern hive beekeeping technology was significant at a level of $10 \%$ and was positively associated with the adoption of technology by the respondents. This demonstrated that educated respondents were more likely to adopt technology than uneducated respondents; this is also in agreement with the findings of Ashraf et al. [67]. The odds ratio in favor of respondent adoption of technology improves by a factor of 2.165 for those who accept the technology, according to the findings. This could be explained by the fact that the respondent has been trained in the use of technology and thus has more knowledge and ability to comprehend than the uneducated. Furthermore, it improves the understanding of the technology, which makes it easier to use the technology. According to Dereje et al. [55], education improves technological understanding, which in turn makes it easier to implement the technology, and the current result is consistent with Wodajo [68]; Yehuala et al. [51]; Adgaba et al. [69]; and Affognon et al. [61]. The adoption of current hive beekeeping technologies was found to be positively and significantly associated with educated respondents. It is advised that the Livestock Production and Fish Resources office create ways for the community's illiterate members to gain more from the use of contemporary hive beekeeping technologies. In addition, the institution must increase its efforts to encourage illiterate farmers in the neighborhood to use technology.

(2) Land Size of Respondents. The variable was statistically significant at $10 \%$ level and was adversely associated with the use of modern hive beekeeping technologies by the respondents in the research area. The negative association indicates that land size and technological adoption are inversely related; also, this study supports the findings in [70], a study on factors affecting the adoption of beekeeping and associated technologies. This means that if all other factors remained unchanged, respondents' technology use would decrease by a factor of 0.002 . One probable explanation is that people with large landholdings may not be interested in beekeeping technology. Because it is safer than forest beekeeping, this type of beekeeping is thought to have more promise. Furthermore, it greatly contributes to the family's income without the need to own farmland [71, 72]. The size of the land of the respondents had a significant and unfavorable impact on their use of technology. This discovery suggested that beekeepers with large landholdings were not adopting technology. This suggests that, in cooperation with the agricultural and natural resource sectors, the livestock and fisheries sectors develop a strategy to assist farmers with vast landholdings who benefit from current hive beekeeping technology..

(3) Extension Contact. The variable was statistically significant at $10 \%$ level and was positively associated with the use of modern hive beekeeping technology by the respondents in the research area. This means that if all other factors remain constant, the respondents' adoption of the technology will increase by a factor of 60.848 if they receive frequent extension contact from experts. Dereje et al. reported a comparable degree of adoption rate in their findings [55]. Good extension services play a major role in dissemination and hence adoption of technologies [70]. The number of extension visits is critical to improving the economic activities of rural households by providing the necessary information on the production and marketing of agricultural products, including honey. This finding is consistent with the findings of Tarekegn et al. [62] who found that the frequency of extension contacts influences honey producers' market outlet choice decisions. Tulu et al. [50] also reported that visiting demonstration locations is a crucial element in increasing beekeeping technology adoption. Tarekegn and Ayele [41] discovered that extension contact has a substantial impact on the technical efficiency of honey producers. However, because beekeepers' educational levels vary, it is critical that beekeeping extension, education, and training have a practical focus and be tailored to the individual needs of the recipient beekeepers [73]. The extension contact of the respondents was found to have a positive and considerable impact on the adoption of modern hive beekeeping technologies. This research clearly demonstrates that more expert extension contact has a favorable impact on farmers' adoption of technology by the respondents. This shows that farmers who interact with extension agents prior to the introduction of new technology are more likely to accept it. Also, youth farmers at the kebele level should be encouraged to participate in modern honey beekeeping technology. Tours to visit the modern beekeeping centers in other regions will provide them with a better understanding of beekeeping activities. A proverbial phrase, "seeing is believing," also helped the visit to other farmers in various regions.

(4) Credit. The variable was statistically significant at 5\% level of significance and was positively related to the adoption of technology by the respondents. This means that if all other factors remained unchanged, the odds ratio in favor of 
responders adopting modern hive beekeeping techniques would grow by a factor of 116.261 for those who received credit. This could be because the respondents require the credit facility to acquire additional colonies, bee wax, and other relevant materials. As a result, the positive sign (coefficient) suggests that as credit grows, so does the likelihood of adopting technology. The present result is in line with the findings of Abrhaley and Rahmeto [43, 44].

Access to financing allows rural people to purchase basic beekeeping equipment and easily adopt modern beekeeping technology. This access can also assist beekeepers in expanding and growing their businesses, thus improving their livelihoods. This finding is consistent with the findings of Tulu et al. [50] who indicated that one of the barriers to adopting advanced beekeeping technologies that can boost honey yield is access to loans. Mulen et al. [75] discovered that the intensity of adoption of beekeeping (i.e., the number of beehives owned) was primarily determined by the membership of beekeepers in a savings or credit group. The lending facility was found to have a considerable and beneficial impact on the respondents' adoption of technology by the respondents. As a result, it is strongly recommended that the Livestock Production and Fish Resource Office link a strategy to a microfinance institution. Farmers who do not have access to credit can still benefit from technological adoption.

(5) Market. The variable was statistically significant at 5\% level of significance and was positively related to respondents' adoption of technology by the respondents. It was found that respondents who have market access to sell honey products had a higher probability of embracing technology than those who do not. This indicates that beekeeping products have a ready market, which should increase household income and lead to further development of the beekeeping sector, and this was found to be in line with the findings of Mujuni et al. [70]; they suggested that beekeeping products have a ready market, which should boost household income and propel the beekeeping industry forward. The odds ratio in favor of the adoption of technology by the respondents increased by58.288 for the respondents with market access, according to the findings. This could be explained by the fact that respondents with market access are more likely to use technology effectively than those without it. This study supports the findings of Belie [52]; Monga and Manocha [53]; Legesse [54]; and Shibru et al. [56] who all concluded that marketing is an important component in honey production. Tulu et al. [50] discovered that one of the determinants of adopting improved beekeeping technology in southwest Ethiopia is the marketing problem. According to Mushonga et al. [76], beekeeping in Kayonza is still largely traditional, employs antiquated production methods, and underuses available marketing channels. The respondents indicated another crucial aspect that influenced the adoption of modern hive beekeeping technologies in a good way: market access. Responders with greater market access were found to be more likely to use technology. As a result, the relevant authorities must devise measures to encourage the use of technology among those who do not have access to the market. Promotional actions concentrate on respondents' lack of market access, which must ensure their active participation in the adoption process.

\subsection{Summary of Qualitative Data Analysis by Focus Group} Discussion (FGD) and Key Informant Interview (KII). The focus group discussion was used in the four sampled kebeles in addition to the material gathered from the home interview schedule to acquire a general picture of the study's stated objectives. Eight modern beekeepers participated in two focus groups. A key informant interview was conducted with two Kebele Administrations, two Development Agents, two Community Elders, one Woreda Agricultural Office, and one Bee specialist to gather some general information in the study area. A focus group discussion (FGD) was held to discuss the adoption of modern hive beekeeping technology and its determinants. The group discussion revealed that the research region is more or less confined to diversification of agricultural and non-agricultural activities of smallholder production due to the low capital of the households' inability to withstand shocks. The population density in the research area is high, and they are not involved in any incomegenerating activities. As a result, during the study year, modern beekeeping absorbed technologies from agriculture and other organizations.

The discussion revealed that a sufficient amount of money, income, training and extension contacts, land ownership, and livestock ownership are all important elements in the adoption of modern hive beekeeping technology. In terms of education, the members stated that those who can read and write have more access to information and a better chance of attending expert training. They also influence farmers' adoption of contemporary hive beekeeping technologies and participate in income-generating diversification initiatives.

Landholding. During the focus group discussion, it was highlighted that the research area is characterized by very small and fragmented landholdings. It is one of the main obstacles that prevent farmers from adopting modern hive beekeeping technologies. As a result, farmers are required to engage in income-generating activities, and the lack of rainfall has led them to employ alternative survival strategies. This was found to be in line with the findings of Gebiso [25]; they suggested that landholding, which is the size of land used for beekeeping, is one of the variables that affects the adoption probability, and in this case, adopters of modern beehives allocated more land for beekeeping. A beekeeper interviewed in May 2016 stated that 'Farmers' adoption behavior is influenced by land-related characteristics, as landholding is an important unit where agricultural operations take place." Many adoption studies found that the size of the farm was strongly related to the adoption of improved technology [34, 35].

Income Sources. Farmers earn money in three ways, according to the focus group discussion. The first is on-farm revenue and the second is off-farm/non-farm income. On- 
TABLE 19: Conversion factors used to calculate the TLU.

\begin{tabular}{lc}
\hline Animal category & TLU \\
\hline Calf & 0.25 \\
Heifer and bulls & 0.75 \\
Cows and oxen & 1.00 \\
Horse & 1.10 \\
Donkey & 0.7 \\
Sheep and goat & 0.13 \\
Poultry & 0.013 \\
\hline
\end{tabular}

Source: Stock et al. [74].

TABLE 20: Contingency coefficient for dummy variables.

\begin{tabular}{|c|c|c|c|c|c|c|c|c|c|}
\hline Variables & Sex & $\begin{array}{c}\text { Extension } \\
\text { contact }\end{array}$ & Training & $\begin{array}{c}\text { Access of } \\
\text { credit }\end{array}$ & $\begin{array}{c}\text { Access of } \\
\text { market }\end{array}$ & $\begin{array}{c}\text { Membership of } \\
\text { cooperatives }\end{array}$ & Perception & $\begin{array}{c}\text { Bee } \\
\text { forage }\end{array}$ & $\begin{array}{c}\text { Honey } \\
\text { pests }\end{array}$ \\
\hline Sex & 1 & 0.221 & 0.106 & 0.018 & -0.188 & 0.187 & 0.120 & 0.098 & -0.111 \\
\hline Extension contact & & 1 & 0.0415 & 0.524 & 0.469 & 0.588 & 0.425 & 0.225 & -0.081 \\
\hline Training & & & 1 & 0.331 & 0.125 & 0.354 & 0.239 & 0.044 & 0.019 \\
\hline Access of credit & & & & 1 & 0.403 & 0.519 & 0.389 & 0.162 & -0.124 \\
\hline Access of market & & & & & 1 & 0.361 & 0.288 & 0.083 & -0.083 \\
\hline $\begin{array}{l}\text { Membership of } \\
\text { cooperatives }\end{array}$ & & & & & & 1 & 0.460 & 0.027 & -0.065 \\
\hline Perception & & & & & & & 1 & 0.131 & -0.126 \\
\hline Bee forage & & & & & & & & 1 & -0.199 \\
\hline Honey pests & & & & & & & & & 1 \\
\hline
\end{tabular}

Source: model output.

TABLE 21: Variance inflation factor (VIF) and tolerance of continuous explanatory variables.

\begin{tabular}{lcc}
\hline Variables & Tolerance & VIF \\
\hline Age & 0.753 & 1.329 \\
Family size & 0.881 & 1.135 \\
Education & 0.704 & 1.420 \\
Total land size & 0.966 & 1.035 \\
Livestock ownership & 0.961 & 1.041 \\
Honey bee colonies & 0.885 & 1.130 \\
\hline
\end{tabular}

Source: model output.

farm income is derived through the sale of crop goods and livestock on the farm. During the conversation and interview, they explained that income from farms comes from crop sales, coffee sales, sales of cattle and livestock products, etc. Sharecropping, remittance, small trade, beekeeping, and labor work with others (relatives/neighbors) are examples of off-farm/non-farm revenue sources. Beekeeping is an offfarm money-generating activity that helps kebele farmers who need additional cash to survive. Furthermore, farmers who work off-farm were more likely to be exposed to information about new farm technology, which improved their knowledge and attitude toward it. They were more likely to learn about modern box hives in their more exposed jobs away from rural farms. The findings agree with those of Yehuala et al. [51] who discovered a favorable relationship between off-farm work and adoption of agricultural technology in their study. A beekeeper interviewed in May 2016 stated that "Beekeepers with off-farm jobs make more money, allowing them to purchase box hives and other necessary equipment for contemporary beekeeping."
Therefore, a "Rural Business Hub" at the woreda level was developed to help the beekeeping business, which includes collection, pricing, and processing of bottles, selling to markets, and transporting to regional and federal markets.

Training by Experts. Farmers earn money in three ways, according to the focus group discussion. The first is on-farm revenue and the second is off-farm/non-farm income. Onfarm income is derived through the sale of crop goods and livestock on the farm. During the conversation and interview, they explained that income from farms comes from crop sales, coffee sales, sales of cattle and livestock goods sales, and so on. Sharecropping, remittance, small trade, beekeeping, and labor work for others (relatives/neighbors) are examples of off-farm/non-farm revenue sources. Beekeeping is an off-farm money-generating activity that helps kebele farmers who need additional cash to survive. "The cops have been offering suitable technical support," said a beekeeper interviewed in questionnaire time (May 2016). Those who do not receive regular servicing from the officers 
eventually abandon the technology, since a small mistake causes the bees to exit the hive. For example, "Last year, I lost two colonies of honey bees from Langstroth hives after relocating them to a location with insufficient shade. It was not until I hired an officer that I learned that maintaining Langstroth hives in the Sun causes overheating, which causes bees to leave the colony. I did as suggested and relocated them to the shade, and the hives now have colonies." "Bees typically do not enjoy contemporary box hives, as they have a painting that generates a fragrance that is unpleasant to bees," said an Extension Officer interviewed on March 15, 2016. However, log hives are normally fashioned from special hardwood trees that have a particularly pleasant smell that local bees are used to. "I have a friend who bought two Langstroth hives last year and has been waiting for bees ever since." Specialized skill-based training is recommended to needy farmers willing to enter the modern hive beekeeping microenterprise business activity.

\section{Conclusions and Recommendations}

Modern hive beekeeping technology adoption has a substantial impact on hive production, since beekeeping may be used as a source of income diversification and even as the principal activity for the majority of rural residents. Despite the fact that practically all beekeepers are aware of the existence of current beehive technology, they have not adopted it for a variety of reasons including personal, economic, institutional, and psychological considerations. The current study found a low rate of adoption of modern hive beekeeping technology in the study areas. Furthermore, the educational level of the respondents, size of the land, extension, contact, access to financing, and market all had a significant impact on the adoption of modern beekeeping technology. Many of the farmers on whom the study was performed were non-adopters, owing to a lack of resources and income. As a result, farmers in this study use modern hive beekeeping technologies to supplement their agricultural production and income. The majority of farmers in the study area lacked the financial means to invest in contemporary hive beekeeping and income-generating activities. As a result, they have adopted modern hive beekeeping equipment, which is critical in the fight against poverty.

\section{Abbreviations}

ARD: Agricultural and rural development

LH: Local hive

KTBH: Kenyan top bar hive

MH: $\quad$ Modern hive

DAs: Development agents

EBA: Ethiopian Beekeepers Association

EMA: Ethiopian Mapping Agency

ESAP: Ethiopian Society of Animal Production

FAO: Food and Agricultural Organization

FTC: Farmer Training Center

HBRC: Holeta Bee Research Center

ILCA: International Livestock Center for Africa

ILRI: International Livestock Research Institute
IPMS: Improving Productivity Market Success

ITK: Indigenous Technical Knowledge

NGOs: Non-Governmental Organizations

PAS: Peasants' Associations

SPSS: Statistical Package for Social Sciences

TTBH: Tanzanian top bar hive.

\section{Appendix}

\section{A. Tropical Livestock Unit}

Table 19 shows the conversion factors used to calculate the TLU.

\section{B. Contingency Coefficient}

Table 20 shows the contingency coefficient for dummy variables.

\section{Continuous Explanatory Variables}

Table 21 shows the variance inflation factor (VIF) and tolerance of continuous explanatory variables.

\section{Data Availability}

The data used to support the findings of this study are available from the corresponding author upon request.

\section{Conflicts of Interest}

The authors declare that they have no conflicts of interest.

\section{References}

[1] Ministry of Finance and Economic Development (MoFED), Layperson's Guide to the Public Budget Progress at Regional Level, MoFED, Addis Ababa, Ethiopia, 2009.

[2] J. Chamberlin and E. Schmidt, "Ethiopian agriculture: a dynamic geographic perspective," ESSP II Working Paper No. 017, 2011.

[3] H. Debebe, "Food aid and its impact on peasant livelihood strategies," in Proceedings of the Food Security and Sustainable Livelihood in Ethiopia, FSS, Addis Abeba Ethiopia, March 2000.

[4] N. Hansjorg, "Food aid: missed opportunity latent potential for poverty reduction and alleviation in Ethiopia," in Proceedings of the Conference on Ethiopian International Institute for Peace and Development, Addis Abeba, Ethiopia, May 2000.

[5] G. W. Zerssa, D. H. Feyssa, D. Kim, and B. EichlerLöbermann, "Challenges of smallholder farming in Ethiopia and opportunities by adopting climate-smart agriculture," Agriculture, vol. 11, p. 192, 2021.

[6] FAO and World Bank, Farming Systems and Poverty, FAO, Rome and Washington, D.C., USA, 2001.

[7] H. Sahle, G. Enbiyale, A. Negash, and T. Neges, “Assessment of honey production system, constraints and opportunities in Ethiopia," Pharmacy and Pharmacology of International Journal, vol. 6, no. 2, pp. 2379-6367, 2018.

[8] N. Bradbear, "Bees and their role in forest livelihoods: a guide to the services provided by bees and the sustainable harvesting, processing and marketing of their products," vol. 19, 2009 Non-Wood Forest Product. 
[9] MoA (Ministry of Agriculture), Comprehensive Bees and Beeswax Development and Marketing Plan (CBMP). 2nd Draft, MoA, Addis Abeba, Ethiopia, 2003.

[10] A. Degenet, K. Belay, and W. Aregay, "Adoption of high yielding maize varieties in Jimma Zone: evidence from farm level data," Ethiopian Journal of Agricultural Economics, vol. 5, pp. 41-62, 2001.

[11] KWADOR, 2015 \&(CSA, 2014) Population Data of KachBirra Woreda.

[12] Ethiopia GIS Version 10.1 Software, 2014.

[13] T. Getachew, B. Melaku, and T. Bereket, "Farmers' perceptions and adaptation strategies to climate change and variability the case of Kacha bira woreda, Kembata Tembaro zone, southern Nations, Nationalities and peoples Ethiopia," Journal of Environment and Earth Science, vol. 7, no. 3, pp. 51-61, 2017.

[14] T. Yamane, Statistics, an Introductory Analysis, Harper and Row, New York, NY, USA, 2nd edition, 1967.

[15] BOARD. Administrative Office. 2015.

[16] BOFED. Administrative Office. 2015.

[17] G. S. Maddala, Limited Dependent and Qualitative Variables in Econometrics, Cambridge University Press, Cambridge, MA, USA, 1983.

[18] W. H. Green, LIMDEP, Version 6.0, Econometric Software, New York, NY, USA, 1991.

[19] M. R. Mohamed, K. S. J. Singh, and C. Y. Liew, "Impact of foreign direct investment \& domestic investment on economic growth of Malaysia," Malaysian Journal of Economic Studies, vol. 50, no. 1, pp. 21-35, 2017.

[20] C. Duze, "Students' and teachers' participation in decisionmaking and impact on school work and school internal discipline in Nigeria," African Research Review, vol. 5, 2011.

[21] G. Danso-Abbeam, D. S. Ehiakpor, and R. Aidoo, "Agricultural extension and its effects on farm productivity and income: insight from Northern Ghana," Agriculture \& Food Security, vol. 7, no. 1, p. 74, 2018.

[22] T. B. Udimal, Z. Jincai, O. S. Mensah, and A. E. Caesar, "Factors influencing the agricultural technology adoption: the case of improved rice varieties (nerica) in the northern region, Ghana," Journal of Economics and Sustainable Development, vol. 8, pp. 137-148, 2017.

[23] E. Wongelu, "Adoption of transitional Chefeka bee hive package: the case of Wolmera Woreda, Oromia Special Zone," MSc. Thesis, Haramaya University, Haramaya, Ethiopia, 2014.

[24] A. Bekuma, "Review on adoption of modern beehive technology and determinant factors in Ethiopia," Journal of Natural Sciences Research, vol. 8, no. 3, pp. 26-29, 2018.

[25] T. Gebiso, "Adoption of modern bee hive in arsi zone of oromia region: determinants and financial benefits," Agricultural Sciences, vol. 6, no. 3, pp. 382-296, 2015.

[26] A. Workneh and R. Puskur, "Beekeeping sub sector challenges and constraints in Atsbi Wemberta district of Eastern Zone, Tigray Region, Ethiopia," Journal of Agricultural Extension and Rural Development, vol. 3, no. 1, pp. 8-12, 2011.

[27] A. Andaregie and T. Astatkie, "Determinants of beekeeping adoption by smallholder rural households in Northwest Ethiopia," Cogent Food \& Agriculture, vol. 7, no. 1, 2021.

[28] Z. Tesfaye and H. Alemu, Adoption of Improved Maize Technologies and Inorganic Fertilizer in North Western Ethiopia, Ethiopian Agricultural Research Organization, Addis Ababa, Ethiopia, 2001.

[29] Y. D. Usman, "Educational resources: an integral component for effective school administration in Nigeria," Research on Humanities and Social Sciences, vol. 6, pp. 27-37, 2016.
[30] E. Kerealem, "Honeybee production system, op-portunities and challenges in Enebse sar midir woreda (Amahara region) and Amaro special woreda (SNNPR), Ethiopia," M.Sc. Thesis, Alemaya University, Alemaya, Ethiopia, 2005.

[31] W. Teferi, "Trends in and determinants of fertilizer use in Gozamin Woreda, Amhara Region,” MSc. Thesis, Haramaya University, Haramaya, Ethiopia, 2003.

[32] A. Workeneh, "Determinants of adoption of improved box hive in Atsbi Wemberta," MSc Thesis, Haramaya University, Haramaya, Ethiopia, 2007.

[33] A. A. Fikadu and K. A. Tilaye, "Adoption and intensity of use of modern bee hives in Wag Himra and North Wollo Zones, Amhara Region, Ethiopia," Agricultural and Resource Economics: International Scientific E-Journal, vol. 3, no. 1, 2018.

[34] M. Taha, "Determinants of intensity of adoption of improved onion production package in Dugda Bora district," MSc. Thesis, Haramaya University, Haramaya, Ethiopia, 2007.

[35] G. Yishak, "Determinants of adoption of improved maize technology in Damote Gale Woreda, Wolaita, Ethiopia,", M.Sc. Thesis, School of Graduate Study of Alemaya University , 2005.

[36] A. Abeje, K. Ayen, M. Awoke, and L. Abebaw, "Adoption and intensity of modern bee hive in Wag Himra and North Wollo Zones, Amhara Region, Ethiopia," Agricultural and Resource Economics: International Scientific E-Journal, vol. 3, no. 1, 2017.

[37] Y. Gidey and T. Mekonen, "Participatory technology and constraints assessment to improve the livelihood of beekeepers in Tigray Region, northern Ethiopia," Momona Ethiopia Journal of Science, vol. 2, no. 1, 2010.

[38] G. Kidane, "Factors influencing the adoption of new wheat and maize varieties in Tigray," MSc. Thesis, Haramaya University, Haramaya, Ethiopia, 2001.

[39] B. Tessega, "Honeybee production and marketing systems, constraints and opportunities in Burie District of Amhara Region, Ethiopia,", thesis, Department of Animal Science and Technology, School of Graduate Studies, Bahirdar University, 2009.

[40] S. K. Ehui, J. Lynam, and I. Okike, "Adapting social science to the changing focus of international agricultural research," in Proceedings of the Rockefeller Foundation. ILCA Social Science Research Fellows Workshop Held at ILCA, pp. 189-203, Addis Ababa, Ethiopia, November 1994.

[41] K. Tarekegn and A. Ayele, "Impact of improved beehives technology adoption on honey production efficiency: empirical evidence from Southern Ethiopia," Agriculture \& Food Security, vol. 9, no. 1, pp. 1-13, 2020.

[42] E. Feder, R. E. Just, and D. Zilberman, "Adoption of agricultural innovations in developing countries: a survey," Economic Development and Cultural Change, vol. 33, pp. 254-297, 1985.

[43] G. Abrhaley, Farmers' Perception and Adoption of Integrated Striga Management Technology, MSc. Thesis, Haramaya University, Haramaya, Ethiopia, 2006.

[44] N. Rahmeto, "Determinants of adoption of improved haricot bean production package in Alaba Special Woreda, Southern Ethiopia," MSc. Thesis, Haramaya University, Haramaya, Ethiopia, 2007.

[45] K. Gratzer, K. Wakjira, and S. Fiedler, "Challenges and perspectives for beekeeping in Ethiopia. A review," Agronomy for Sustainable Development, vol. 41, p. 46, 2021.

[46] S. Rahman, "Adoption of improved technologies by the pig farmers of Aizawal district of Mizoram, India," Livestock Research for Rural Development, vol. 19, p. 5, 2007. 
[47] G. Adeday, M. Shiferaw, and F. Abebe, "Prevalence of bee lice Braula coeca (Diptera: braulidae) and other perceived constraints to honey bee production in Wukro Woreda, Tigray Region, Ethiopia," Global Veterinaria, vol. 8, no. 6, pp. 631635, 2012.

[48] K. Welay and T. Tekleberhan, "Honey-bee production practices and hive technology preferences in jimma and illubabor zone of oromiya regional state, Ethiopia," Acta Universitatis Sapientiae, Agriculture and Environment, vol. 9, pp. 31-43, 2017.

[49] A. Missiame, R. A. Nyikal, and P. Irungu, "What is the impact of rural bank credit access on the technical efficiency of smallholder cassava farmers in Ghana? An endogenous switching regression analysis," Heliyon, vol. 7, no. 5, Article ID e07102, 2021.

[50] D. Tulu, M. Aleme, G. Mengistu, A. Bogale, A. Bezabeh, and E. Mendesil, "Improved beekeeping technology in southwestern Ethiopia: focus on beekeepers' perception, adoption rate and adoption determinants," Cogent Food \& Agriculture, vol. 6, no. 1, Article ID 1814070, 2020.

[51] S. Yehuala, M. Birhan, and D. Melak, "Perception of farmers towards the use of modern beehives technology in Amhara region, Ethiopia," European Journal of Biological Sciences, vol. 5, no. 1, pp. 1-8, 2013.

[52] T. Belie, Honeybee Production and Marketing Systems, Constraints and Opportunities in Burie District of Amhara Region, Ethiopia, MSc Thesis, Bahir Dar University, Bahir Dar, Ethiopia, 2009.

[53] K. Monga and A. Manocha, "Adoption and constraints of beekeeping in district panchkula (Haryana), India," Livestock Research for Rural Development, vol. 23, no. 5, pp. 1-19, 2011.

[54] G. Y. Legesse, "Review of progress in Ethiopian honey production and marketing," Livestock Research for Rural Development, vol. 26, no. 1, pp. 1-6, 2014.

[55] T. Dereje, A. Melkam, M. Gezahegn, B. Ararsa, B. Amsalu, and M. Esayas, "Improved beekeeping technology in Southwestern Ethiopia: focus on beekeepers' perception, adoption rate, and adoption determinants," Cogent Food \& Agriculture, vol. 6, no. 1, Article ID 1814070, 2020.

[56] D. Shibru, G. Asebe, and E. Megersa, "Identifying opportunities and constraints of beekeeping: the case of gambella zuria and godere weredas, gambella regional state, Ethiopia," Entomology, Ornithology \& Herpetology: Current Research, vol. 5, p. 182, 2016.

[57] J. Manda, M. G. Khonje, A. D. Alene et al., "Does cooperative membership increase and accelerate agricultural technology adoption? Empirical evidence from Zambia," Technological Forecasting and Social Change, vol. 158, Article ID 120160, 2020.

[58] B. W. Feyisa, "Determinants of agricultural technology adoption in Ethiopia: a meta-analysis," Cogent Food \& Agriculture, vol. 6, 2020.

[59] R. Roberts, R. Flin, D. Millar, and L. Corradi, "Psychological factors influencing technology adoption: a case study from the oil and gas industry," Technovation, vol. 102, Article ID 102219, 2021.

[60] G. Melaku, B. Shifa, T. Azage, A. Nigatu, and B. Lulseged, "Approaches, methods and processes for innovative apiculture development: experience from ada'a- liben wereda, oromiya, Ethiopia," IPMS Working Paper 8, ILRI, Addis Ababa, Ethiopia, 2008.

[61] H. Affognon, D. Kingori, W. S. Omondi et al., "Adoption of modern beekeeping and its impact on honey production in the former Mwingi District of Kenya: assessment using theory- based impact evaluation approach," International Journal of Tropical Insect Science, vol. 35, no. 2, pp. 96-102, 2015.

[62] K. Tarekegn, J. Haji, and B. Tegegne, "Determinants of honey producer market outlet choice in Chena District, southern Ethiopia: a multivariate probit regression analysis," Agricultural and Food Economics, vol. 5, no. 1, p. 20, 2017.

[63] FAO, "Bees and their role in forest livelihoods: a guide to the services provided by bees and the sustainable harvesting, processing and marketing of their products by nicola bradbear," p. 204, 2009 Paper 19.

[64] A. Gidey, S. Mulugeta, and A. Fromsa, "Prevalence of bee lice braula coeca (Diptera: braulidae) and other perceived constraints to honey bee production in wukro woreda, tigray region, Ethiopia," Global Veterinaria, vol. 8, no. 6, pp. 631-635, 2012.

[65] J. Dabessa and A. Belay, "Survey on major honey bee pests and predators in Oromia special zone surrounding Finfine in Walmara District," European Journal of Biological Sciences, vol. 7, no. 2, pp. 62-70, 2015.

[66] W. Kiros and T. Tsegay, "Honey-bee productions practices and hive technology preferences in jimma and illubabor zone of oromiya regional state, Ethiopia," Agriculture and Environment, vol. 9, pp. 31-43, 2017.

[67] S. Ashraf, G. A. Khan, S. Ali, and M. Iftikhar, "Socio-economic determinants of the awareness and adoption of citrus production practices in Pakistan," Ciência Rural, vol. 45, no. 9, pp. 1701-1706, 2015.

[68] W. A. Wodajo, "Financial benefits of box hive and the determinants of its adoption in selected district of Ethiopia," American Journal of Economics, vol. 1, no. 1, pp. 21-29, 2011.

[69] N. Adgaba, A. Al-Ghamdi, A. G. Shenkute et al., "Socioeconomic analysis of beekeeping and determinants of box hive technology adoption in the kingdom of Saudi Arabia," The Journal of Animal \& Plant Sciences, vol. 24, no. 6, pp. 1876-1884, 2014.

[70] A. Mujuni, K. Natukunda, and D. R. Kugonza, "Factors affecting the adoption of beekeeping and associated technologies in Bushenyi District, Western Uganda," Livestock Research for Rural Development, vol. 24, p. 133, 2012.

[71] A. Sebsib and T. Yibrah, "Beekeeping practice, opportunities, marketing and challenges in Ethiopia: review," Dairy Vet Sci, vol. J5, no. 3, pp. 1-21, 2018.

[72] B. Serda, T. Zewudu, M. Dereje, and M. Aman, "Beekeeping practices, production potential and challenges of bee keeping among beekeepers in Haramaya District, Eastern Ethiopia," Journal of Veterinary Science \& Technology, vol. 6, no. 255, pp. 1-5, 2015.

[73] C. N. Schouten, “Factors influencing beekeepers' income, productivity and welfare in developing countries: a scoping review," Journal of Apicultural Research, vol. 60, no. 2, pp. 204-219, 2021.

[74] R. A. Stock, J. M. Lewis, T. J. Klopfenstein, and C. T. Milton, "Review of new information on the use of wet and dry milling feed by-products in feedlot diets," Journal of Animal Science, vol. 77, pp. 1-12, 2021.

[75] D. R. Mulen, M. D’Haese, E. Ahikiriza et al., "The buzz about bees and poverty alleviation: identifying drivers and barriers of beekeeping in Sub-Saharan Africa," PLoS One, vol. 12, no. 2, Article ID e0172820, 2017.

[76] B. Mushonga, L. Hategekimana, G. Habarugira, E. Kandiwa, A. Samkange, and B. V. E. Segwagwe, "Characterization of the beekeeping value chain: challenges, perceptions, limitations, and opportunities for beekeepers in Kayonza District, Rwanda," Advances in Agriculture, vol. 2019, Article ID 5982931, 13 pages, 2019. 